behaviour, race and sexual orientation is new, arguments and attitudes about the significance of these traits are not. Scientists have a responsibility to do what they can to prevent abuses of their work, including the way it is communicated. Here are some pointers.

First: be patient. Do not speculate about the possibility of finding certain results, or about the implications of those results, before your data have even been analysed. The BGI Cognitive Genomics group in Shenzhen, China, is studying thousands of people to find genes that underlie intelligence, but group members sparked a furore by predicting that studies such as theirs could one day let parents select embryos with genetic predispositions to high intelligence. Many other geneticists are sceptical that the project will even find genes linked to this trait.

Second: be accurate. Researchers should design studies on the basis of sound scientific reasoning. For instance, in light of increasing evidence that race is biologically meaningless, research into genetic traits that underlie differences in intelligence between races, or that predispose some races to act more aggressively than others, will produce little. Furthermore, it is common for small studies of behavioural genetics to go unreplicated, and there are increasing concerns that the science of behaviour more generally suffers from poor practice, exaggeration and irreproducibility (see Nature http://doi.org/n2m; 2013). Scientists should refrain from claiming that they have found a basis for any complex trait until the results have been replicated and confirmed in large, definitive studies, such as multiple meta-analyses.

Third: be sensitive. Even if scientists have truly honourable intentions, they must realize how easy it can be for studies on socially favoured groups to seem self-serving. For instance, BGI's study of exceptionally intelligent individuals is itself led by people who are unusually bright, even in the cognitively enriched domain of science: there is a child prodigy who dropped out of high school to work on genomics; a physicist who graduated from university at age 19; and an International Mathematical Olympiad gold medallist. When such people make statements in favour of selecting embryos for intelligence, it can seem to the public as if the researchers think that society would benefit from the birth of more people just like them - even if this is not what they have in mind.

Finally: be proactive. Once scientists are sure of their results, they
"Scientists have a responsibility to do what they can to prevent abuses of their work." usually do their best to explain the significance of their work in academic publications. But these texts are often impenetrable to the public and may include technical terms that can be misinterpreted by non-specialists. To provide clarity, scientists would do well to follow the example of the Social Science Genetic Association Consortium. In June, this group published a paper on genetic variants associated with educational attainment (C. A. Rietveld et al. Science 340, 1467-1471; 2013). Accompanying this was a nine-page Frequently Asked Questions document that, in plain, easy-to-understand language, addressed such questions as why the researchers did the study, what they found and what the implications of the work are - and are not (see go.nature. $\mathrm{com} / 7 \mathrm{mov} 2 \mathrm{j}$ ). The document spelled out that the consortium had not found 'the gene' for educational attainment, that each genetic marker found has only a very small effect on length of schooling, and that any policy response based on that single study would be premature.

Scientists cannot be held responsible every time someone misinterprets their work. But simple steps such as these could help to prevent and address some of the potential distortions of behavioural genetics - and could help to ensure that society continues to support the work. .

\section{Cross the road}

\author{
Research on chickens is legitimate - but \\ scientists and funders must learn to justify it.
}

\section{$\mathrm{T}$} axpayers underwrite many public services, including the funding of science. So it is entirely right for them to question funding decisions. If they do, granting agencies should have mechanisms for responding in ways that are informed but not patronizing.

On 18 September, the UK Arts and Humanities Research Council (AHRC) announced nine grants, most of which aimed to bridge the gap between science and the humanities. The majority were uncontroversial. Nobody blinked, for example, at the $£ 1.95$ million (US\$3.1 million) given to Colin Blakemore of the Institute of Philosophy in London for a project entitled 'Rethinking the Senses: Uniting the Philosophy and Neuroscience of Perception'. No eyebrow was raised when Randolph Donahue at the University of Bradford got $£ 1.98$ million to study 'Fragmented Heritage: From the kilometre to the nanometre: Automated 3D Technology to Revolutionise Landscape, Site and Artefact Analyses'.

But when Mark Maltby at Bournemouth University was awarded $£ 1.94$ million for 'Cultural and Scientific Perceptions of HumanChicken Interactions', the reaction from some tabloid newspapers was predictable. "A birdbrained idea? Outrage as academics are handed $£ 2 \mathrm{~m}$ to study how humans interact with CHICKENS," crowed The Daily Mail. "Chicken study costing $£ 1.9$ million of taxpayers' funds causes a flap," squawked The Daily Express.

Why the outrage? Could it be that journalists came across the AHRC press release, recognized the word 'chicken' in the morass of science-speak and went for an easy sell - lambasting the indulgence of barmy boffinry with taxpayers' money at a time of austerity? Why 'easy'? Well, whereas not many people know much about neuroscience or nanometres, everyone knows what chickens are. So much so that they feel they can take interactions with the birds for granted, and ask what more we would learn by spending almost $£ 2$ million on the subject. It is in that familiarity, however, that the questions lie. We know surprisingly little about the history of human-chicken relations, such as how chickens first came to Britain.

Behind the over-excited headlines lies a legitimate question about accountability. If it is right and proper for researchers, rather than politicians, to decide how public funds should be spent (the 'Haldane principle'), then those researchers should be ready to justify such decisions, promptly and simply. For example, after Greger Larson of Durham University appeared on radio and television this year to talk about his work on the domestication of dogs, he received an e-mail that demanded, bluntly, whether the $£ 1$ million being spent on such a subject came from the taxpayer. Larson replied with a polite, informative and, most importantly, personal e-mail explaining where the money came from - and how it fitted into the context of UK government funding.

The denigration of science by media outlets and some politicians relies on an us-against-them mentality. This can be weakened by individual personal engagement such as Larson's. Many corporations are breaking down barriers by interacting with customers through social media such as Twitter and Facebook, replying to comments much faster than they would through more conventional, formal channels. Customers appreciate the speed of service and the fact that it can be personalized, and come to feel more engaged with that corporation's aims.

Research bodies have not been slow to use such media. The AHRC, for example, has a Twitter feed (@ahrcpress), as does the Natural Environment Research Council, which funded Larson (@NERCscience). It is only a matter of time before taxpayers communicate $\rightarrow$ NATURE.COM To comment online, click on Editorials at: go.nature.com/xhunqv routinely with researchers using such methods. Informal networks will help the public to become more engaged with the work that their money funds - demonstrating the value, if you like, of human-human interactions. 